\title{
Health significance of cadmium induced renal dysfunction: a five year follow up
}

\author{
H A ROELS, R R LAUWERYS, J P BUCHET, A M BERNARD, A VOS, \\ M OVERSTEYNS
}

From the Unité de Toxicologie Industrielle et Médecine du Travail, School of Medicine, Catholic University of Louvain, 1200 Brussels, Belgium

ABSTRACT To assess the health significance of the early renal changes after chronic exposure to cadmium, 23 workers removed from exposure because of the discovery of an increased urinary excretion of $\beta_{2}$-microglobulin or retinol binding protein, or both, have been examined once a year for five years. Eight of these workers had also an increased albuminuria. These workers had been exposed to cadmium for six to 41.7 years (mean 25 years) and their first follow up examination took place when they had been removed from exposure for six years on average. At that time, their mean age was $58 \cdot 6$ years (range: $45 \cdot 5-68 \cdot 1$ ). It has been confirmed that the proteinuria induced by cadmium is irreversible. The most important finding, however, is a significant increase of creatinine and $\beta_{2^{-}}$ microglobulin concentrations in serum with time, indicating a progressive reduction of the glomerular filtration rate despite removal from exposure. It is estimated that on average this rate has decreased by $31 \mathrm{ml} / \mathrm{min} / 1.73 \mathrm{~m}^{2}$ during the five year follow up study. This decrease is significantly greater (about five times) than that accounted for by aging and is not more pronounced in workers with impaired renal function at the start of the study than in those presenting only with subclinical signs of renal damage. Serum alkaline phosphatase activity also increases significantly with time. In conclusion, the present study indicates that the early renal changes induced by cadmium should be regarded as adverse effects; they are predictive of an exacerbation of the age related decline of the glomerular filtration rate.

The kidney is the critical organ after long term exposure to cadmium (Cd). An increased urinary excretion of plasma proteins usually represents the earliest biological sign of cadmium interference with kidney function. It is known that cadmium can decrease the tubular reabsorption of low molecular weight proteins-for example $\beta_{2}$-microglobulin and retinol binding protein (RBP). An enhanced glomerular filtration of high molecular weight proteins such as albumin may also represent an early manifestation of excessive exposure to cadmium. ${ }^{12}$ Since both nephron sites may be concomitantly affected by cadmium, it has frequently been assumed that the microalbuminuria of cadmium nephropathy also results from an impairment of tubular reabsorption. Nevertheless, recent investigations from our laboratory on the renal handling of plasma proteins ${ }^{3}$ and on the mechanism of cadmium action on the kidney $^{4}$ have shown that a reduction of the polyanionic charges of the glomerular basement

Accepted 19 December 1988 membrane may be responsible for the early albuminuria.

The health significance of the enhanced excretion of plasma proteins after chronic exposure to cadmium remains a matter of controversy. ${ }^{5}$ Cadmium proteinuria is usually irreversible ${ }^{6-8}$ but no conclusive data are available to assess whether it is predictive of a progressive alteration of renal function. To get some insight into this problem, we have followed up workers who were no longer exposed to cadmium because of the discovery of an increased urinary excretion of $\beta_{2}$-microglobulin or RBP, or both, alone or associated with albuminuria.

\section{Subjects and methods}

STUDY POPULATION

Twenty three male workers, previously exposed to cadmium oxide dust and fume in two non-ferrous smelters, volunteered to be examined once a year for five consecutive years. These workers had been exposed to cadmium for nearly 25 years on average 
(range 6 to 41.7 years) and had been removed from exposure because of the finding of an enhanced excretion of $\beta_{2}$-microglobulin ( $\left.>300 \mu \mathrm{g} / \mathrm{l} ; \mathrm{n}=18\right)$ or $\operatorname{RBP}(>300 \mu \mathrm{g} / \mathrm{l} ; \mathrm{n}=17)$, or both. Eight had also an increased albuminuria $(>20 \mathrm{mg} / \mathrm{l})$. At the time of removal from exposure to cadmium, the concentrations of serum creatinine were normal $(<13 \mathrm{mg} / \mathrm{l})$ in 18 subjects, marginally increased in three $(13.3,13.7$, $13.9 \mathrm{mg} / \mathrm{l})$, and raised in two $(20.3$ and $22.3 \mathrm{mg} / \mathrm{l})$. Their first follow up examination took place when they had been removed from cadmium exposure for six years on average. At that time 17 workers were retired and six were still occupationally active but in jobs with no exposure to cadmium. They were invited once a year for a medical check up in the medical department of the factory where they had been previously employed. About three years before the first survey, 21 of these workers also had their concentrations of cadmium in liver and in kidney measured by neutron activation analysis. ${ }^{910}$ The cadmium concentrations $(\mu \mathrm{g} / \mathrm{g}$ wet weight $)$ in liver and in kidney cortex ranged from 24 to 158 (mean 61) and from 133 to 355 (mean 231), respectively. Examination of medical records and the medical questionnaires collected at the start of the study did not disclose previous or current diseases or drug consumption habits that might interfere with renal function. In particular, none of the cadmium workers had a history of hypertension, gout, urinary tract infection, renal stone, acute lead poisoning, or regular consumption of analgesics. The job history of each worker was also reconstructed; special attention was paid to possible past exposure to other heavy metals, particularly lead. Eleven workers had spent their whole professional life in the cadmium department of the plants where there was no risk of excessive exposure to lead. Four workers had initially been occupied (6-17 years) in other departments before being transferred to the cadmium department for the rest of their professional life (14-40 years). None had ever been engaged in jobs where a lead risk was considered to be present. Eight subjects had initially been assigned to the cadmium department (for 7-29 years) and were then moved to other jobs when a tubular proteinuria was discovered. For six of them the new job did not involve exposure to lead. The other two workers may have been slightly exposed to lead for six years but the biological monitoring data found in their medical records indicate that their exposure to lead has never been excessive since the concentration of $\delta$-aminolaevulinic acid in urine has never exceeded $5 \mathrm{mg} / \mathrm{l}$.

Two groups of control male subjects (volunteers) were also examined, one at the time of the first survey and the other at the end of the study. They were matched for age with the cadmium workers but they had never been occupationally exposed to heavy metals, such as cadmium and lead, and were in good $\frac{\varrho}{3}$ clinical health (no history of diabetes or kidney or $\frac{\mathbb{Q}}{Q}$ cardiovascular diseases). The first control group included 23 subjects, aged 46 to $69($ mean $=58 \cdot 8)$ and $\overrightarrow{\vec{F}}$ the second 23 subjects, aged 50 to $74($ mean $=63 \cdot 3)$.

METHODS

At each survey, the workers were questioned about $\overparen{\AA}$ their health status and drug consumption and a sample of venous blood $(20 \mathrm{ml})$ and urine $(100 \mathrm{ml})$ was ${ }^{\infty}$ collected. The examination took place between $0900 \vec{\circ}$ and 1200 , the subjects having had a light breakfast. Since the study had to be performed on ambulatory $\omega$ subjects, only spot urine samples were obtained. The 0 following biological analyses were made using stan- $\frac{\mathbb{D}}{3}$ dardised or previously published methods: cadmium in blood and in urine, ${ }^{11}$ lead in blood, ${ }^{12}$ total proteins ${ }^{1} \stackrel{\square}{\longrightarrow}$ and amino acids ${ }^{13}$ in urine, $\beta_{2}$-microglobulin in serum and in urine,${ }^{14} \mathrm{RBP}$ in urine, ${ }^{14}$ albumin in urine,${ }^{14} \delta$ aminolaevulinic acid in urine,,$^{15}$ creatinine in urine ${ }^{16} \mathrm{~N}$ and in serum, ${ }^{17}$ packed cell volume, zinc protopor- ${ }^{\circ}$ phyrin in erythrocytes (ZPP) using a haemato- $\vec{z}$ fluorimeter (Aviv Associates, Lakewood, NJ), alk-O aline phosphatase activity and uric acid in serum, ${ }^{16}$ and $\Phi$ calcium in serum and in urine by flame atomic $\frac{}{\sigma}$ absorption spectrometry using a Varian Techtron, $\stackrel{\mathbb{\Phi}}{-}$ model 1100. Quality control programmes were run $\vec{\bullet}$ during the whole study period to exclude analyticgilo bias.

\section{STATISTICAL ANALYSIS}

The data collected during the five surveys werē analysed by variance analysis. A paired $t$ test was useç to compare the results of some parameters measured $B$ at the beginning and at the end of the follow up period $\overrightarrow{\overrightarrow{0}}$ Differences between the prevalences of abnormaB values found at the first and last survey were ascer $\vec{z}$ tained by a one tailed binomial test or a McNemar $\chi$ t. test. $^{18}$ Association between variables was evaluated byo Pearson's correlation coefficients and Student's $t$ tese was used to assess the significance of the differences between the controls and the cadmium workers. ${ }^{19}$ Fop. $\beta_{2}$-microglobulin, RBP, albumin, and total protein in urine, the statistical treatment was applied after log transformation. Differences were considered statiso tically significant if $\mathrm{p}<0.05$.

\section{Results}

CADMIUM WORKERS
The table summarises the main characteristics of the cadmium workers and the results of several biologicaf parameters measured at each survey. A variance analysis showed that cadmium concentration in bloo $\mathbb{E}$ and in urine significantly $(p<0.001)$ decreased witk time, whereas $\beta_{2}$-microglobulin, creatinine, and alk 
aracteristics and biological parameters of 23 male subjects with signs of cadmium induced renal changes and removed from exposure to mium:* summary of a five year follow up

\begin{tabular}{|c|c|c|c|c|c|}
\hline & \multicolumn{5}{|l|}{ Surveys } \\
\hline & lst & $2 n d$ & $3 r d$ & $4 t h$ & $5 t h$ \\
\hline $\begin{array}{l}:(y) \\
\text { irs of removal from } \\
\text { mium exposure }\end{array}$ & $\begin{aligned} 58.6 & \pm 1.38 \dagger \\
6.0 & \pm 0.86\end{aligned}$ & $\begin{array}{r}59.7 \pm 1.37 \\
7.1 \pm 0.87\end{array}$ & $\begin{array}{r}61.1 \pm 1.37 \\
8.6 \pm 0.83\end{array}$ & $\begin{array}{r}62.3 \pm 1.37 \\
9.6 \pm 0.82\end{array}$ & $\begin{array}{l}63.3 \pm 1.37 \\
10.7 \pm 0.83\end{array}$ \\
\hline $\begin{array}{l}\text { ne: } \\
\text { 'admium }(\mu \mathrm{g} / \mathrm{l}) \\
\text { 'alcium }(\mathrm{mg} / \mathrm{l}) \\
\text { 'roteins }(\mathrm{mg} / \mathrm{l}) \ddagger \\
\text { Imino acids }(\mathrm{mg} \alpha-\mathrm{N} / \mathrm{l}) \\
\text { '-microglobulin }(\mu \mathrm{g} / \mathrm{l}) \ddagger \\
\text { lBP }(\mu \mathrm{g} / \mathrm{l}) \ddagger \\
\text { llbumin }(\mathrm{mg} / \mathrm{l}) \ddagger \\
\text { 'reatinine }(\mathrm{g} / \mathrm{l})\end{array}$ & $\begin{array}{cl}22 \cdot 2 & \pm 2 \cdot 93 \\
179 & \pm 28 \\
226 & (60-1395) \\
184 & \pm 16 \\
1770 & (31-48,900) \\
1570 & (171-66,000) \\
23 & (3 \cdot 1-517) \\
1 \cdot 37 \pm 0 \cdot 12\end{array}$ & $\begin{array}{cl}16 \cdot 0 & \pm 2 \cdot 28 \\
159 & \pm 20 \\
236 & (70-1312) \\
164 & \pm 15 \\
1550 & (24-129,000) \\
985 & (95-88,000) \\
18 & (2 \cdot 5-220) \\
1 \cdot 23 \pm 0 \cdot 10\end{array}$ & $\begin{array}{cl}15 \cdot 5 & \pm 1 \cdot 60 \\
143 & \pm 16 \\
235 & (20-1126) \\
209 & \pm 17 \\
2560 & (48-165,000) \\
1260 & (28-96,000) \\
25 & (1 \cdot 9-207) \\
1 \cdot 52 \pm 0 \cdot 16\end{array}$ & $\begin{array}{cl}15 \cdot 6 & \pm 2 \cdot 08 \\
141 & \pm 21 \\
168 & (9-1669) \\
185 & \pm 19 \\
2570 & (43-170,000) \\
1870 & (41-106,000) \\
26 & (2 \cdot 5-330) \\
1 \cdot 34 & \pm 0 \cdot 13\end{array}$ & $\begin{array}{cl}18 \cdot 0 & \pm 2.98 \\
150 & \pm 18 \\
293 & (35-1624) \\
200 & \pm 19 \\
2580 & (66-123,000) \\
2000 & (59-100,000) \\
30 & (5 \cdot 0-425) \\
1.48 \pm 0.11\end{array}$ \\
\hline $\begin{array}{l}\text { ole blood: } \\
\text { 'acked cell volume (\%) } \\
\text { Jadmium }(\mu \mathrm{g} / \mathrm{l})\end{array}$ & $\begin{array}{l}43.6 \pm 0.62 \\
14.3 \pm 2.0\end{array}$ & $\begin{array}{l}43.0 \pm 0.60 \\
11.8 \pm 1.4\end{array}$ & $\begin{array}{l}43.1 \pm 0.65 \\
10.1 \pm 0.9\end{array}$ & $\begin{array}{rll}42.5 & \pm 0.78 \\
9.3 & \pm 0.8\end{array}$ & $\begin{aligned} 42.5 & \pm 0.76 \\
9.7 & \pm 0.9\end{aligned}$ \\
\hline $\begin{array}{l}\text { um: } \\
\text { Jreatinine (mg/l) } \\
\text { Jalcium (mg/l) } \\
\text { llkaline pase (IU/l) } \\
\text { Jric acid (mg/l) } \\
\}_{2} \text {-Microglobulin (mg/l) }\end{array}$ & $\begin{array}{l}12 \cdot 0 \pm 1 \cdot 1 \\
89.5 \pm 1 \cdot 0 \\
37 \pm 2 \cdot 3 \\
40 \pm 0.0 \\
1.89 \pm 0.19\end{array}$ & $\begin{array}{l}13.5 \pm 1.3 \\
88.5 \pm 0.7 \\
41 \pm 2.8 \\
38 \pm \pm 2.2 \\
2.07 \pm 0.18\end{array}$ & $\begin{array}{l}13.9 \pm 1.4 \\
86.9 \pm 0.8 \\
33 \pm 1.7 \\
38 \pm 2.2 \\
2.35 \pm 0.26\end{array}$ & $\begin{array}{ll}15.3 & \pm 1.6 \\
87.2 & \pm 0.8 \\
43 & \pm 2.7 \\
43 & \pm 2.9 \\
2.63 & \pm 0.32\end{array}$ & $\begin{array}{ll}15.1 & \pm 2.2 \\
90.7 & \pm 0.9 \\
54 & \pm 3.7 \\
42 & \pm 2.7 \\
3.00 & \pm 0.42\end{array}$ \\
\hline
\end{tabular}

uration of exposure to cadmium: mean (SEM) range; $24.9(1.97) 6.0-41 \cdot 7$ years.

ean \pm SEM.

eometric mean and (range).

aline phosphatase in serum significantly $(\mathrm{p}<0.001)$ increased with time. On an individual basis, the other parameters did not exhibit a statistically significant time trend. For each worker, the results of biological parameters measured during the last four surveys have been expressed in percentages of the corresponding first survey results; the mean of these percentages and their $\mathbf{9 5 \%}$ confidence interval are shown in figs 1 and 2.

Figure 3 illustrates for all the examined workers the decrease of cadmium concentration in blood $(p<0.005)$ and in urine $(0.1>p>0.05)$ between the first and the last (about five years later) survey, whereas fig 4 shows the increase of the three most affected parameters, creatinine $(p<0.025), \quad \beta_{2}-$ microglobulin $(p<0.001)$, and alkaline phosphatase $(p<0.001)$ in serum between the first and the last survey. We have determined whether the prevalence of raised values of some urine or serum parameters increased with time using the following cut off levels: (urine) total proteins $>200 \mathrm{mg} / 1$, amino acids $>200 \mathrm{mg} \alpha-\mathrm{N} / 1, \beta_{2}$-microglobulin $>300 \mu \mathrm{g} / \mathrm{l}$, RBP $>300 \mu \mathrm{g} / \mathrm{l}$, albumin $>20 \mathrm{mg} / \mathrm{l}$; (serum) alkaline phosphatase activity $>60 \mathrm{IU} / \mathrm{l}$, creatinine $>13 \mathrm{mg} / \mathrm{l}, \beta_{2^{-}}$ microglobulin $>2 \mathrm{mg} / \mathrm{l}$. For urinary parameters, the prevalences of abnormal values did not vary sig- nificantly as shown by the values obtained on the first and the last surveys: total proteins $48 v 61 \%$, amino acids $35 v 43 \%, \beta_{2}$-microglobulin $78 v 83 \%$, RBP $74 v 83 \%$, albumin $35 v 39 \%$. The prevalence of abnormal serum alkaline phosphatase activity did not increase significantly between the first and last survey (4 $v 13 \%)$; on the contrary, the prevalences of raised values increased significantly between the first and the fifth survey for serum creatinine $(30 v 52 \%)$ $(\mathrm{p}<0.05)$ and serum $\beta_{2}$-microglobulin $(30 \vee 74 \%)$ $(\mathrm{p}<0.01)$. The time dependent increase of the serum concentration of creatinine and $\beta_{2}$-microglobulin during the follow up study is statistically significant whether one considers either the total population $(n=23)$ or the 21 subjects with serum creatinine below $15 \mathrm{mg} / \mathrm{l}$ at the start of the survey or only the 13 subjects with pure tubular proteinuria and normal concentrations of serum creatinine $(<13 \mathrm{mg} / \mathrm{l})$ and serum $\beta_{2}$-microglobulin $(<2 \mathrm{mg} / \mathrm{l})$ at the start of the survey (fig 5). Creatinine and $\beta_{2}$-microglobulin concentrations in serum were found to be highly correlated with each other. For example, at the last survey, the correlation coefficient between log creatinine in serum and $\log \beta_{2}$-microglobulin in serum amounted to $0.86(\mathrm{p}<0.001)$. The correlation remained highly significant $(r=0.80 ; p<0.01)$ when 

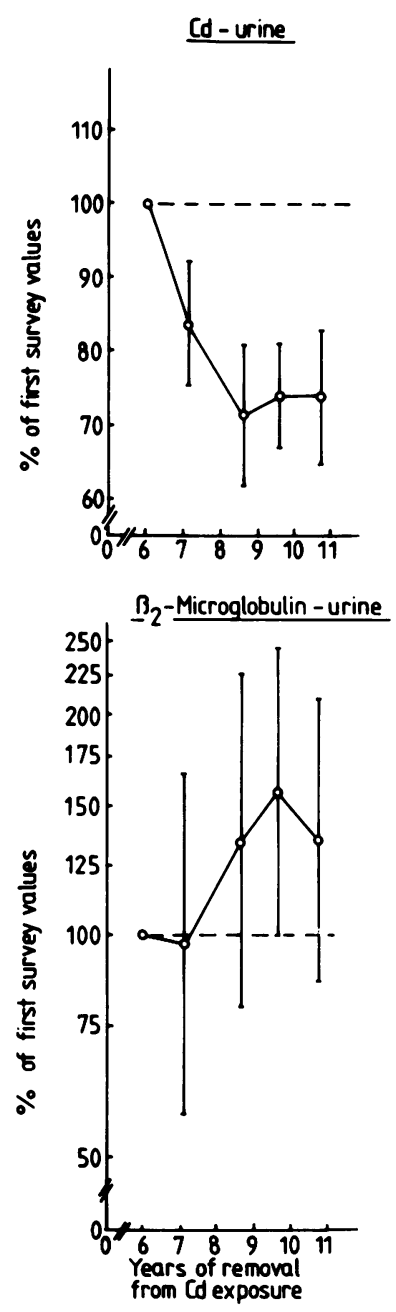
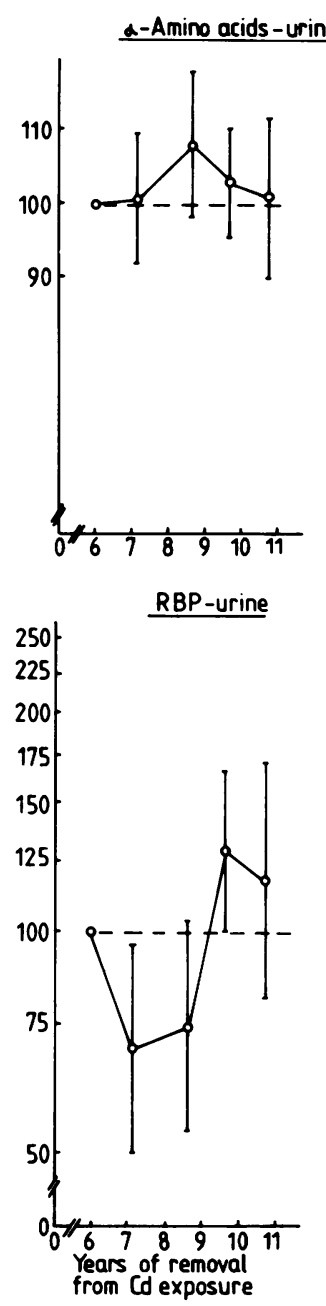

Roels, Lauwerys, Buchet, Bernard, Vos, Oversteyns
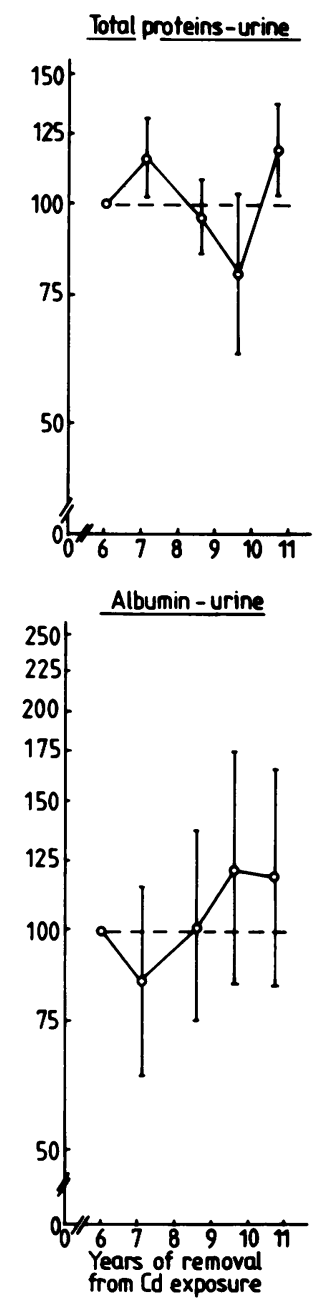

Fig 1 Cadmium workers: time course of urinary parameters after removal from exposure to cadmium (mean \pm 95\% confidence interval; $n=23$ ).

it was recalculated using only the values $(n=20)$ of serum creatinine and serum $\beta_{2}$-microglobulin lower than $20 \mathrm{mg} / 1$ and $4 \mathrm{mg} / 1$, respectively.

Although direct measurements of the glomerular filtration rate (GFR) could not be performed in this follow up study, we thought that it would be useful to estimate indirectly the magnitude of GFR decrease on the basis of the increased serum concentrations of $\beta_{2^{-}}$ microglobulin. ${ }^{20}$ In the absence of malignancy the latter parameter is a better indicator of GFR ${ }^{20-25}$ than serum creatinine since the rate of $\beta_{2}$-microglobulin production is not body mass dependent as is creatinine. Figure 6 illustrates the pronounced reduction in estimated GFR over the five year follow up study on an individual and on a group basis. All the subjects showed a decrease of the estimated GFR; the decreases between the first and fifth survey ranged: from 9 to $78 \mathrm{ml} / \mathrm{min} / 1.73 \mathrm{~m}^{2}$ (paired $t$ test, $\mathrm{p}<0.001$ ). Furthermore, on a group basis, the decrease is lineari with time as shown by the regression correlation 3 between the estimated GFR at each survey (group mean) and the corresponding number of years afterremoval from exposure to cadmium $(r=-0.99$; $\mathrm{p}<0.001$ ). According to the regression line for the total population, the average decrease in GFR bet- $N$ ween the start and the end of the follow up periodthat is, after 4.7 years - amounts to $31 \mathrm{ml} / \mathrm{min} / \mathrm{N}$ $1.73 \mathrm{~m}^{2}$. Similar results are obtained when considering $\omega$ separately the 21 subjects with serum creatinine below $15 \mathrm{mg} / \mathrm{l}$ at the start of the survey (decrease in estimatedo GFR $=31 \mathrm{ml} / \mathrm{min} / 1.73 \mathrm{~m}^{2}$ ) or the 13 subjects with pure tubular proteinuria and normal serum creatinine 

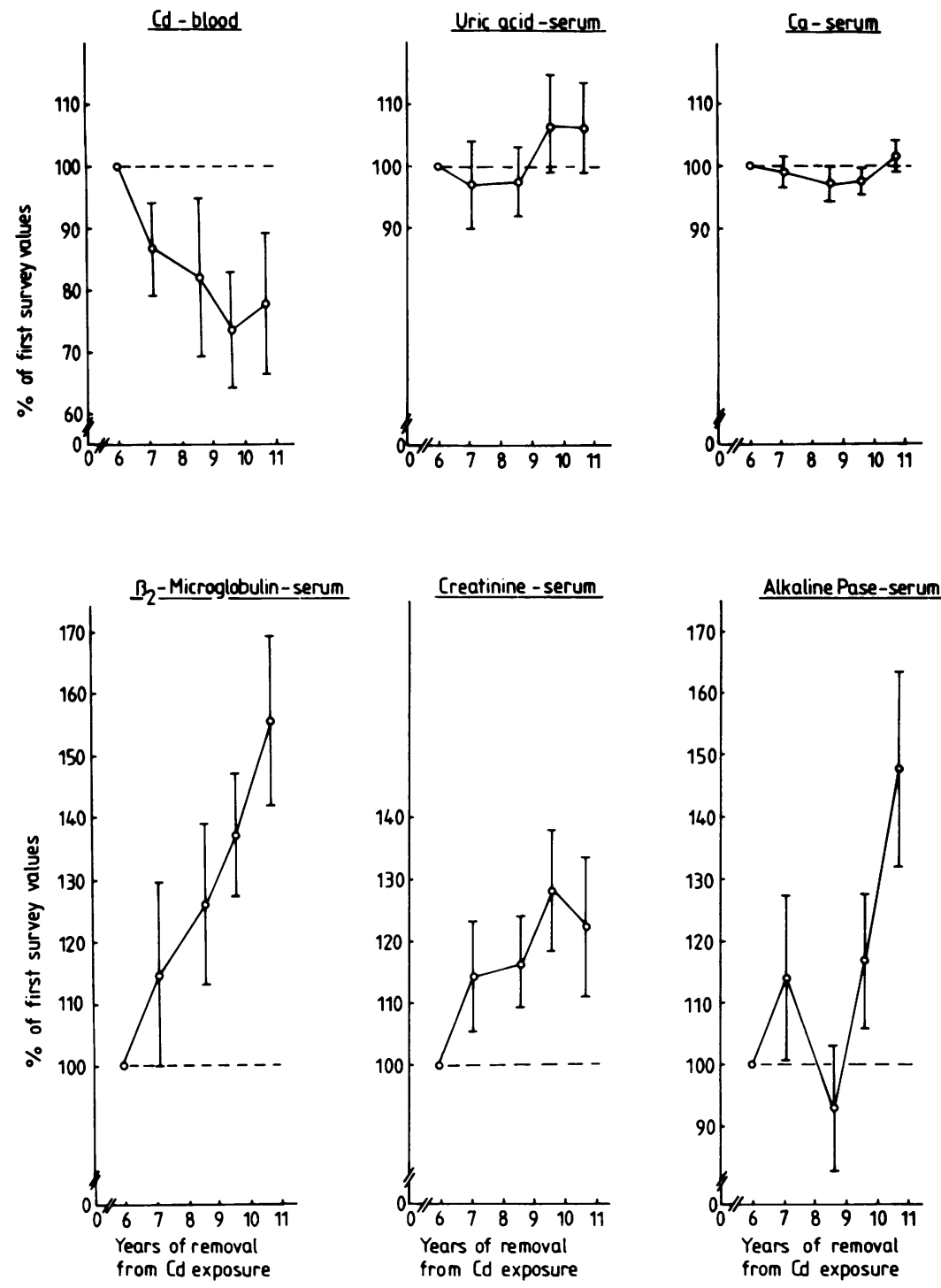

Fig 2 Cadmium workers: time course of blood and serum parameters after removal from exposure to cadmium (mean $\pm 95 \%$ confidence interval; $n=23$ ). 

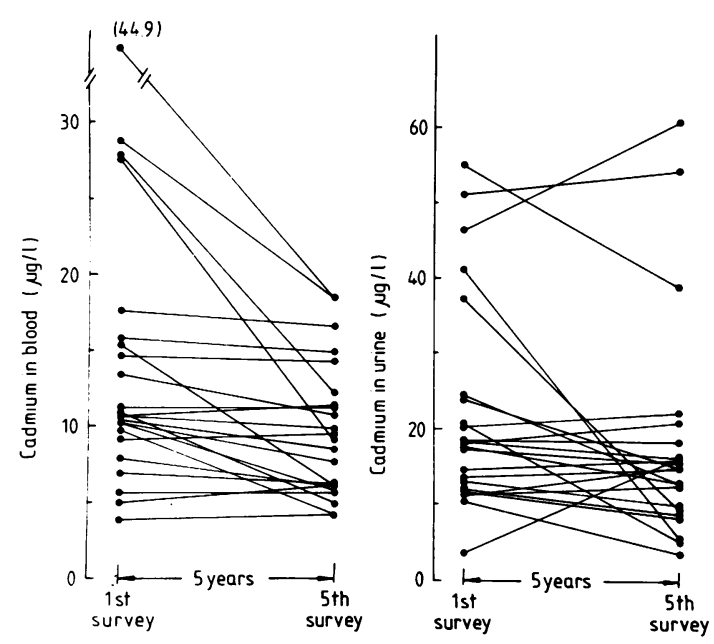

Fig 3 Cadmium workers: cadmium concentrations in blood and in urine at first (six years after removal from exposure) and at fifth survey (nearly 11 years after removal from exposure). Paired t test $(n=23)$ : cadmium in blood, $p<0.005$; cadmium in urine, $0.1>p>0.05$.
Roels, Lauwerys, Buchet, Bernard, Vos, Oversteyns $\overline{\bar{z}}$ CONTROL SUBJECTS

All the results of the various biological parameters 3

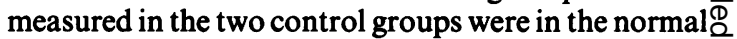
range (data not shown) except for eight subjects who $\Rightarrow$ had serum creatinine concentrations above $13 \mathrm{mg} / \mathrm{lo}$ (range 13.7-16.2) and for 10 subjects who had serumo $\beta_{2}$-microglobulin concentrations above $2 \mathrm{mg} / \mathrm{l}$ (range 흘 $2 \cdot 1-3 \cdot 3$ ). Figure 5 shows the mean values of the serum $\frac{\bar{c}}{5}$ creatinine and serum $\beta_{2}$-microglobulin concentrations $\mathbb{D}$ in both groups. All the control subjects had normalo concentrations of cadmium in urine $(<2 \mu \mathrm{g} / \mathrm{l})$ and $^{\mathrm{es}}$ lead in blood $(<350 \mu \mathrm{g} / \mathrm{l})$. The ZPP concentrations. were also normal. In the first control group the GFR $\overrightarrow{\vec{H}}$ values (estimated from the serum $\beta_{2}$-microglobulin concentration) ranged from 58 to 121 (mean \pm SEM: $90 \pm 3 \cdot 2$ ), whereas in the second group they ranged $\exists$ from 46 to $132 \mathrm{ml} / \mathrm{min} / 1.73 \mathrm{~m}^{2}$ (mean $\pm \mathrm{SEM}: 91 \pm$ के $4 \cdot 1)$.

\section{Discussion}

The results of this prospective study on workers removed from exposure to cadmium because of the finding of an enhanced urinary excretion of some
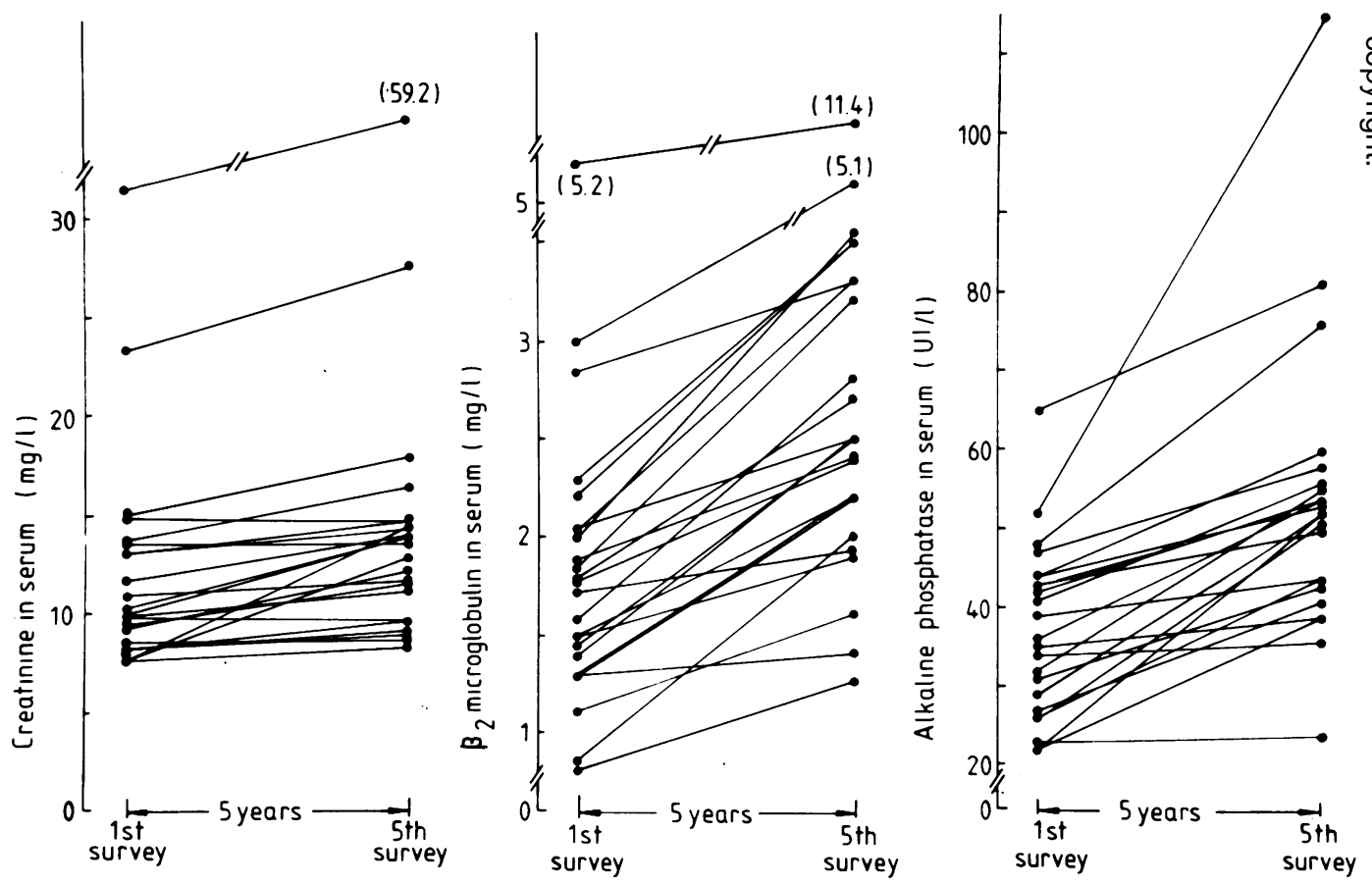

Fig 4 Cadmium workers: creatinine, $\beta_{2}$-microglobulin, and alkaline phosphatase activity in serum at first (six years after removal from exposure) and at fifth survey (nearly 11 years after removal from exposure). Paired $t$ test $(n=23)$ : creatinine, $p<0.025 ; \beta_{2}$-microglobulin, $p<0.001$; alkaline phosphatase, $p<0.001$. 

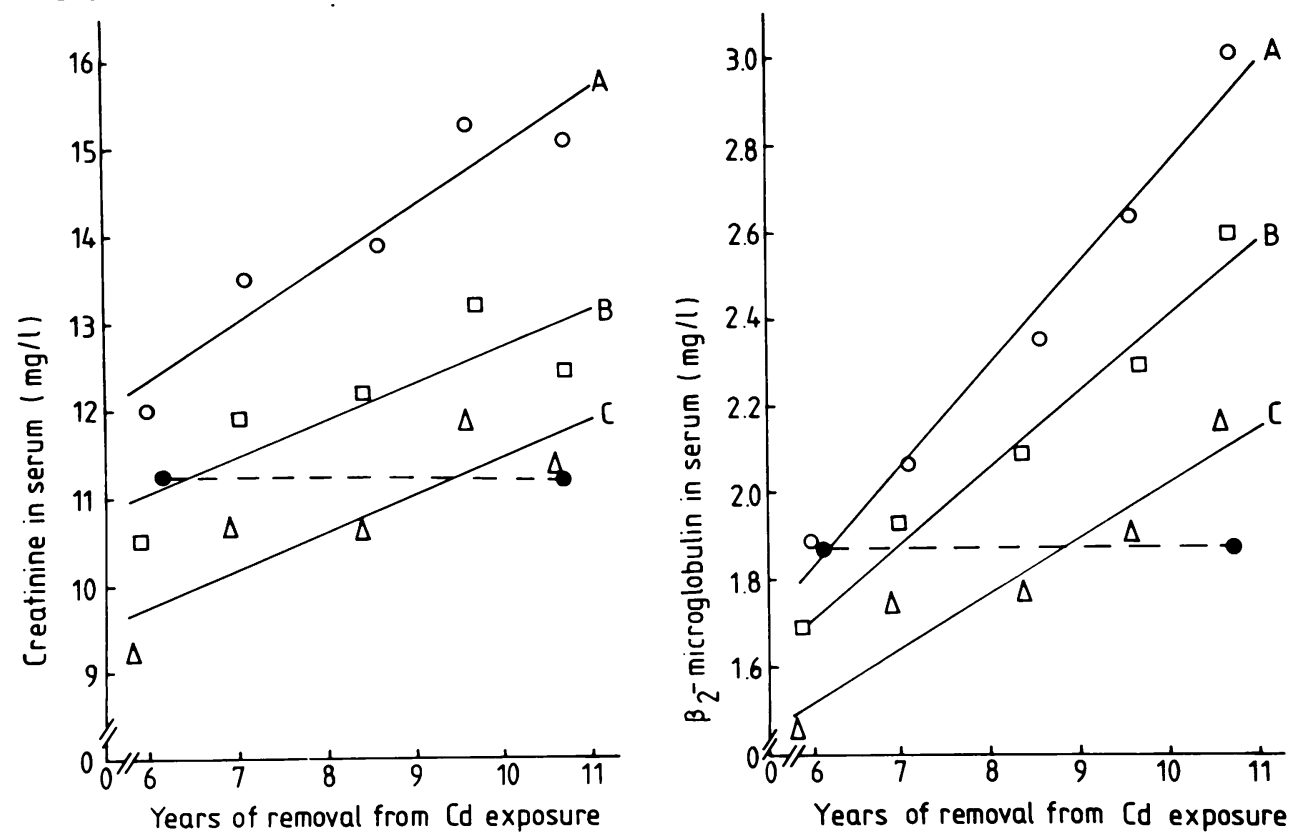

Fig 5 Relations between group means $(n=5)$ of creatinine or $\beta_{2}$-microglobulin concentrations in serum and time after removal from exposure to cadmium in three different subgroups of workers exposed to cadmium. $\bigcirc$ Total population $(n=23)$ : serum creatinine, $r=0.94, p<0.02$; serum $\beta_{2}$-microglobulin, $r=0.99, p<0.01$. $\square$ Cadmium workers with serum creatinine below $15 \mathrm{mg} / \mathrm{l}$ at start of study $(n=21)$ : serum creatinine, $r=0.83, p \simeq 0.05$; serum $\beta_{2}$-microglobulin, $r=0.99, p<0.01 . \triangle$ Cadmium workers with pure tubular proteinuria and normal concentrations of serum creatinine $(<13$ $\mathrm{mg} / \mathrm{l})$ and serum $\beta_{2}$-microglobulin $(<2 \mathrm{mg} / \mathrm{l})$ at start of study $(n=13)$ : serum creatinine, $r=0.83, p \simeq 0.05 ;$ serum $\beta_{2^{-}}$ microglobulin, $r=0.95, p<0.02$. Mean values of serum creatinine and serum $\beta_{2}$-microglobulin in two age matched control groups (each 23 subjects).

plasma proteins $\left(\beta_{2}\right.$-microglobulin or RBP, or both, alone or associated with albumin) confirm those obtained previously but which were based on a retrospective examination of the data collected by our laboratory. ${ }^{6}$ The conclusions drawn previously were only tentative since the design of the study did not permit the exclusion of possible bias due to loss of follow up. The proteinuria induced by cadmium is not reversible. None of the values of urinary RBP, $\beta_{2}$ microglobulin, and albumin, which were significantly enhanced at the time of the first survey, had returned to the normal concentration five years later. Serum alkaline phosphatase activity significantly increased during the five year follow up period; this may reflect an interference of cadmium with bone metabolism, possibly secondary to a reduction in the conversion of 25-hydroxycholecalciferol to 1,25-dihydroxycholecalciferol by the kidney. ${ }^{26}$

The increase of serum creatinine and serum $\beta_{2^{-}}$ microglobulin (fig 5) with time observed in the present prospective study on workers removed from exposure to cadmium clearly indicates a progressive reduction of the GFR despite removal from exposure to cadmium. On the basis of the concentrations of $\beta_{2}$ microglobulin in serum, ${ }^{20}$ it may be estimated that during the five year follow up study, the GFR of the examined cadmium workers has decreased on average by $31 \mathrm{ml} / \mathrm{min} / 1 \cdot 73 \mathrm{~m}^{2}$ (fig 6 ). The normal age related decline of the GFR has been studied by several authors (for a review ${ }^{27}$ ) and it may be estimated that in the age range 45 to 75 the expected decline (dashed line in fig 6) over five years should normally not exceed $6.5 \mathrm{ml} /$ $\mathrm{min} / 1.73 \mathrm{~m}^{2}$. All the cadmium workers had during the follow up period of five years a reduction of their estimated GFR which is greater (on average about five times) than that value.

By contrast, both control groups had similar mean values for creatinine and $\beta_{2}$-microglobulin in serum, 11.2 and $1.9 \mathrm{mg} / 1$ respectively (fig 5), and the mean estimated GFR values in those two control groups $(90$ and $91 \mathrm{ml} / \mathrm{min} / 1.73 \mathrm{~m}^{2}$, respectively) are in the normal range $^{27} 28$ for these age groups (mean age 58.8 and 63.3 years, respectively). The mean estimated GFR in the first control group does not significantly differ from 

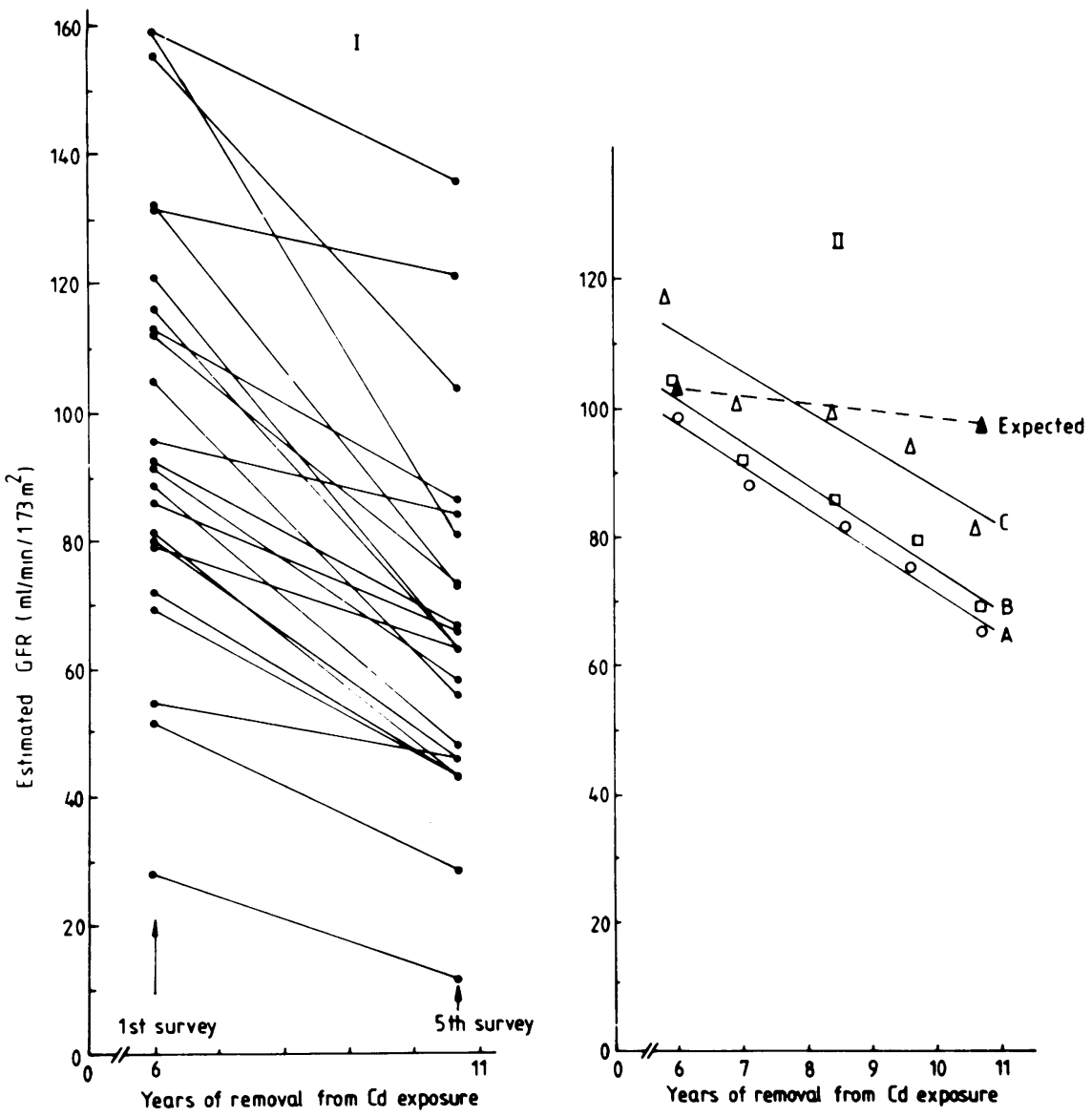

Fig 6 Estimated glomerular filtration rate (based on concentration of serum

$\beta_{2}$-microglobulin).I

Cadmium workers: individual values at first $\mathbb{D}$ and fifth survey (paired $t \mathrm{~g}$ test: $p<0.001)$. II Relations between group $\overrightarrow{0}$ means $(n=5)$ of estimated GFR and time $\vec{\omega}$ after removal from exposure to cadmium in three different subgroups of workers exposed to cadmium (same subgroups as in fig 5$) .0$. $r=-0.99(p<0.01)$, जु slope $-6.6 \mathrm{ml} / \mathrm{min} / 1.73 \mathrm{O}$ $m^{2} /$ year; $\square r=-0.98 \mathrm{~S}$ $(p<0.01)$, slope $-6.6 \rightarrow$ $\mathrm{ml} / \mathrm{min} / 1.73 \mathrm{~m}^{2} /$ year; $\triangle \mathrm{Z}$ $r=-0.93(p<0.02)$, slope $-6.3 \mathrm{ml} / \mathrm{min} / 1.73$ $\mathrm{m}^{2} /$ year. Expected age related decline in GFR $(\Delta--\Delta)$ is about 1.3 $\cap \overrightarrow{0}$ $\mathrm{ml} / \mathrm{min} / 1.73 \mathrm{~m}^{2} /$ year aso estimated from published. data. ${ }^{27}$

that found in the cadmium workers at the first survey, whereas that in the second control group is significantly higher $(\mathrm{p}<0.001)$ than that found in the cadmium workers at the last survey (mean \pm SEM: $65 \pm 5.9 \mathrm{ml} /$ $\min / 1.73 \mathrm{~m}^{2}$ ). This confirms that during the follow up period, the age related decline of the GFR in the cadmium workers is significantly greater than that accounted for by aging.

The job history of the cadmium workers allows us to conclude that excessive occupational exposure to lead is not a confounding factor. The measured concentration of lead in blood, $\delta$-aminolaevulinic acid in urine, and ZPP in blood indicate that the lead body burden of these workers was not sufficient to cause or aggravate the observed renal effect. ${ }^{29}{ }^{30}$ Furthermore, according to Alessio et al, in workers removed from exposure to lead a mean ZPP level of $1.6 \mu \mathrm{g} / \mathrm{g} \mathrm{Hb}$ would correspond to a urinary excretion of lead after intravenous administration of $1 \mathrm{~g}$ calcium edetate of about $500 \mu \mathrm{g} /$ $24 \mathrm{~h},{ }^{31}$ a value lower than that which may be associated with some degree of renal insufficiency in non-gouty patients. ${ }^{32}$

Two hypotheses may be suggested to explain the glomerular impairment induced by cadmium. This $\mathbb{D}$ could result $(a)$ from the development of a certain degree of interstitial nephritis secondary to the tubular 3 lesion or $(b)$ independently from its tubular effectsi cadmium may also exert toxic effects in the glomerulus. The first hypothesis is commonly invoked to explain the decrease of GFR in workers exposed to 3 cadmium. ${ }^{33} 34$ In a follow up of cadmium workers who had first been examined 13 years previously Piscator found that a slight tubular dysfunction was not $/ 0$ accompanied by a reduction of GFR whereas the GFR was decreased in a few subjects with more severe요 tubular dysfunction, which according to the authors $\omega$ means that the reduction in GFR follows the tubular and interstitial changes. ${ }^{35}$

The present study offers arguments against the first $\Phi$ hypothesis. Firstly, the increase in serum creatinine 
and serum $\beta_{2}$-microglobulin (or the decline in estimated GFR) found in cadmium workers occurs in the absence of significant aggravation of the tubular impairment (figs 1 and 2). Furthermore, by contrast with the observations by Piscator ${ }^{835}$ and Elinder et $a l l^{36}$ no relation was found between the degree of tubular impairment observed at the beginning of the follow up study and the subsequent drop in estimated GFR. The correlation coefficients between the relative increase in serum creatinine or serum $\beta_{2}$-microglobulin (or the relative decrease of the estimated GFR) and the urinary excretion of $\beta_{2}$-microglobulin and RBP were statistically not significant.

Our observations are better explained by the second hypothesis, that of a progressive and independent impairment of glomerular function induced by cadmium. Several human and experimental data demonstrating an interference of cadmium with glomerular function at an early stage of the intoxication support this conclusion: (a) Kjellström and Piscator have reported data showing that increased serum concentrations of $\beta_{2}$-microglobulin, which, as stated by these authors probably result from a decreased GFR, may occur in workers exposed to cadmium with normal urinary $\beta_{2}$-microglobulin excretion ${ }^{37} ;$ a similar observation has been reported recently by other Swedish investigators ${ }^{7} ;(b)$ in Japan, Nogawa et al have suggested that a reduction in creatinine clearance may be detected at the early stage of chronic cadmium poisoning in $\operatorname{man}^{38} ;(c)$ in cadmium workers a microalbuminuria may precede the onset of tubular proteinuria $^{39}$ (and unpublished observations); (d) chronic administration of cadmium to rats $(100 \mathrm{ppm}$ in drinking water) gives rise to an isolated albuminuria which precedes the rise of $\beta_{2}$-microglobulinuria by several months ${ }^{40} ;(e)$ our recent studies on workers and on rats chronically exposed to cadmium show that this metal can induce a microalbuminuria by reducing the negative charges on the glomerular capillary wall. ${ }^{4}$

It should, however, be recognised that in cadmium workers the presence of a microalbuminuria is not a prerequisite for predicting a loss of glomerular function because $(a)$ a significant increase in serum creatinine and serum $\beta_{2}$-microglobulin and a significant reduction in the estimated GFR $(\geqslant 30 \mathrm{ml} / \mathrm{min} /$ $1.73 \mathrm{~m}^{2}$ ) during the five year observation period were also found in workers who had only an increased urinary excretion of low molecular weight proteins at the first survey (figs 5 and 6 ), and (b) the relative increase in serum creatinine and serum $\beta_{2}$-microglobulin (or the relative decrease in the estimated GFR) did not differ significantly between workers with or without increased albuminuria at the first survey.

The present study allows us to conclude that the early renal changes induced by cadmium - that is, the increased urinary excretion of low (and high) molecular weight proteins - should be regarded as adverse effects; they predict an exacerbation of the age related decline of the GFR. This study suggests that in addition to the measurement of the urinary excretion of specific plasma proteins such as RBP and albumin, the health surveillance programme of workers exposed to cadmim would benefit from the inclusion of serum $\beta_{2}$-microglobulin determination in order to detect a reduction of the GFR as early as possible. It would also be useful to assess whether an increased cadmium burden which has not yet caused an enhanced urinary excretion of plasma proteins may also affect the age related decline of renal function. Such knowledge is particularly relevant for assessing the validity of the proposed biological limit values for cadmium in urine $(10 \mu \mathrm{g} / \mathrm{g}$ creatinine) and in blood $(10 \mu \mathrm{g} / \mathrm{l})$ which mainly aim to prevent the occurrence of increased specific proteinuria. ${ }^{41}$

\section{Appendix}

$\begin{array}{ll}\text { CONVERSION OF UNITS } \\ \text { Cadmium } & 1 \mu \mathrm{g}=8.90 \mathrm{nmol} \\ \text { Lead } & 1 \mu \mathrm{g}=4.83 \mathrm{nmol} \\ \text { Calcium } & 1 \mathrm{mg}=25.0 \mu \mathrm{mol} \\ \text { Creatinine } & 1 \mathrm{mg}=8.84 \mu \mathrm{mol} \\ \text { Aminolaevulinic acid } & 1 \mathrm{mg}=7.63 \mu \mathrm{mol} \\ \text { Uric acid } & 1 \mathrm{mg}=6.33 \mu \mathrm{mol}\end{array}$

This study was supported by a grant from the International Lead Zinc Research Organization.

A M Bernard is Chercheur Qualifié du Fonds National Belge de la Recherche Scientifique.

We are grateful to Messrs $\mathbf{H}$ Bauer, J Casters, X Dumont, T Seminck, and Miss C Gathy for their skilful technical help.

Requests for reprints to: $\mathbf{R} \mathbf{R}$ Lauwerys, Unité de Toxicologie Industrielle et Médecine du Travail, Catholic University of Louvain, 30.54 Clos Chapelleaux-Champs, B-1200 Brussels, Belgium.

\section{References}

1 Lauwerys R, Buchet JP, Roels H, Brouwers J, Stanescu D. Epidemiological survey of workers exposed to cadmium: effect on lung, kidney, and several biological indices. Arch Environ Health 1974;28:145-8.

2 Lauwerys RR, Bernard A, Roels HA, Buchet JP, Viau C. Characterization of cadmium proteinuria in man and rat. Environ Health Perspect 1984;54:147-52.

3 Bernard A, Viau C, Ouled A, Lauwerys R. Competition between low and high molecular weight proteins for renal tubular uptake. Nephron 1987;45:115-8.

4 Bernard AM, Ouled Amor A, Lauwerys RR. Decrease of ery- 
throcyte and glomerular membrane negative charges in chronic cadmium poisoning. $\mathrm{Br} J$ Ind $\mathrm{Med}$ 1988;45:112-5.

5 Lauwerys RR, Bernard AM. Cadmium and the kidney. Br J Ind Med 1986;43:433-5

6 Roels H, Djubgang J, Buchet JP, Bernard A, Lauwerys RR. Evolution of cadmium-induced renal dysfunction in workers removed from exposure. Scand J Work Environ Health 1982; 8:191-200.

7 Elinder CG, Edling C, Lindberg E, Kågedal B, Vesterberg O. $\beta_{2}-$ Microglobulinuria among workers previously exposed to cadmium: follow-up and dose-response analysis. Am J Ind Med 1985;8:553-64.

8 Piscator $M$. The progress of renal dysfunction in cadmiumexposed workers. In: Wilson D, Volpe RA, eds. Proceedings of the fourth international cadmium conference, Munich, 1983. London: Cadmium Association, New York: International Lead Zinc Research Organization, 1983:157-60.

9 Roels H, Lauwerys RR, Buchet JP, et al. In vivo measurement of liver and kidney cadmium in workers exposed to this metal. Environ Res 1981;26:217-40.

10 Roels H, Lauwerys RR, Dardenne AN. The critical level of cadmium in human renal cortex: a reevaluation. Toxicol Lett 1983;15:357-60.

11 Roels H, Buchet JP, Lauwerys RR, et al. Lead and cadmium absorption among children near a nonferrous metal plant. A follow-up study of a test case. Environ Res 1978;15:290-308

12 Roels HA, Lauwerys RR, Buchet JP, Bernard A. Environmental exposure to cadmium and renal function of aged women in three areas of Belgium. Environ Res 1981;24:117-30.

13 Bernard A, Roels H, Hubermont G, Buchet JP, Masson PL, Lauwerys RR. Characterization of the proteinuria in cadmiumexposed workers. Int Arch Occup Environ Health 1976;38:19-30.

14 Bernard A, Lauwerys RR. Continuous flow system for the automation of latex immunoassay. Clin Chem 1983;29:1007-11.

15 Lauwerys RR, Delbroeck R, Vens MD. An automated analysis of delta-aminolevulinic acid in urine. Clin Chim Acta 1972;40: 443-7.

16 Henry RJ. Clinical chemistry: principles and technics. 3rd ed. New York: Harper and Row, 1965

17 Heinegård B, Tiderström G. Determination of serum creatinine by a direct colorimetric method. Clin Chim Acta 1973;43:305-10.

18 Siegel S. Nonparametric statistics: for the behavioral sciences. (International student ed.) Tokyo: McGraw-Hill Kogakusha, 1956.

19 Snedecor GW. Statistical methods applied to experiments in agriculture and biology. Ames: Iowa State University Press, 1956.

20 Wibell L, Evrin PE, Berggård I. Serum $\beta_{2}$-microglobulin in renal disease. Nephron 1973;10:320-31.

21 Braren V, Goddard J, Brill AB, Touya JJ. $\beta_{2}$-Microglobulin as renal diagnostic agent. Urology 1979;13:624-8.

22 Viberti GC, Keen H, Mackintosh D. $\boldsymbol{\beta}_{2}$-Microglobulinaemia: a sensitive index of diminishing renal function in diabetes. $\mathrm{Br} \mathrm{Med}$ $J$ 1981;282:95-8.

23 Edwards LC, Helderman JH, Hamm LL, Ludwin D, Gailiunas P $\mathrm{Jr}$, Hull AR. Non-invasive monitoring of renal transplant function by analysis of $\beta_{2}$-microglobulin. Kidney Int 1983;
Roels, Lauwerys, Buchet, Bernard, Vos, Oversteyns 23:767-70.

24 Kult J, Lämmlein Ch, Röckel A, Heidland A. $\beta_{2}$-Mikroglobulin in Serum-ein Parameter des Glomerulumfiltrates. Deutsch Medizinische Wochenschrift 1974;99:1686-8.

25 Portman RJ, Kissane JM, Robson AM, Peterson LJ, Richardson: A. Use of $\beta_{2}$-microglobulin to diagnose tubulo-interstitial rena lesions in children. Kidney Int 1986;30:91-8.

26 Nogawa K, Tsuritani I, Kido T, Honda R, Yamada Y, Ishizaki M Mechanism for bone disease found in inhabitants environmen-음 tally exposed to cadmium: decreased serum $1 \alpha, 25$-dihydroxy $\overline{-\infty}$.

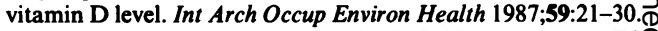

27 Lindeman RD. Kidney: kidney and body fluids. In: Masoro EJ, $\varrho$ ed. Handbook of physiology in aging. Boca Raton, Florida: CRC Press, 1981:173-93.

28 Hernando Avendaño L, Lopez Novoa JM. Glomerular filtration $\vec{\rho}$ and renal blood flow in the aged. In: Macias Nuñez JF $\rightarrow$ Cameron JS, eds. Renal function and disease in the elderly $\vec{\omega}$ London: Butterworths, 1987:27-48.

29 Buchet JP, Roels H, Bernard A, Lauwerys RR. Assessment of renal function of workers exposed to inorganic lead, cadmium or mercury vapour. J Occup Med 1980;22:741-50.

30 Buchet JP, Roels H, Bernard A, Lauwerys RR. Assessment op renal function of workers simultaneously exposed to inorganic lead and cadmium. J Occup Med 1981;23:348-52.

31 Alessio L, Bertazzi PA, Monelli O, Foffoletto F. Free erythrocyte protoporphyrin as an indicator of the biological effect of lead in adult males. Int Arch Occup Environ Health 1976;38:77-86.

32 Wedeen RP, Mallik DK, Batuman V. Detection and treatment of occupational lead nephropathy. Arch Int Med 1979;139:53-7. Z

33 Friberg L, Elinder CG, Kjellström T, Nordberg GF. Cadmium and health: a toxicological and epidemiological appraisal. Vol II Boca Raton, Florida: CRC Press, 1986.

34 Piscator M. The nephropathy of chronic cadmium poisoning. In Foulkes EC, ed. Cadmium: handbook of experimental pharmacology. Vol 80. Berlin: Springer-Verlag, 1986:179-94.

35 Piscator M. Long-term observations on tubular and glomeroparoo function in cadmium-exposed persons. Environ Health Persyect 1984;54:175-9.

36 Elinder CG, Edling C, Lindberg E, Kågedal B, Vesterberg早 Assessment of renal function in workers previously exposed to cadmium. Br J Ind Med 1985;42:754-60.

37 Kjellström T, Piscator M. Quantitative analysis of $\beta_{2}$-microglobulin in urine as an indicator of renal tubular damage induced $b$, cadmium. Uppsala: Diagnostic Communications, Pharmacia Diagnostics AB, 1977:3-21. (Phadedoc No 1.)

38 Nogawa K, Kobayashi E, Honda R, Ishizaki A, Kawano $S \supset$ Matusda $H$. Renal dysfunction of inhabitants in a cadmiumpolluted area. Environ Res 1980;23:13-23.

39 Bernard A, Buchet JP, Roels H, Masson P, Lauwerys RR. Renalexcretion of proteins and enzymes in workers exposed to cadmium. Eur J Clin Invest 1979;9:11-29.

40 Bernard A, Lauwerys RR, Gengoux P. Characterization of the proteinuria induced by prolonged oral administration of cad $\frac{5}{3}$ mium in female rats. Toxicology 1981;20:345-57.

41 Lauwerys RR. Industrial chemical exposure: guidelines for bio logical monitoring. Davis, California: Biomedical Publications 1983:17-22. 